\title{
Faktor-faktor yang mempengaruhi pertumbuhan ekonomi sektor kehutanan dan dampaknya terhadap kesempatan kerja
}

\author{
Muhammad Hasbul Syafrani ${ }^{1}$, Rusdiah Iskandar ${ }^{2}$, Irwan Gani ${ }^{3}$ \\ Magister Ilmu Ekonomi, Fakultas Ekonomi dan Bisnis Universitas Mulawarman, Samarinda \\ ${ }^{1}$ Email: muhammad.hasbul.syafrani@mhs.feb.unmul.ac.id \\ ${ }^{2}$ Email: rusdiah.iskandar@feb.unmul.ac.id \\ ${ }^{3}$ Email: irwan.gani@feb.unmul.ac.id
}

\begin{abstract}
Abstrak
Penelitian ini dilakukan bertujuan untuk Menganalisis pengaruh tenaga kerja subsektor Kehutanan secara signifikan terhadap pertumbuhan ekonomi sektor Kehutanan di Kabupaten Berau. Menganalisis pengaruh Investasi Pemerintah sektor Kehutanan secara signifikan terhadap pertumbuhan ekonomi sektor Kehutanan di Kabupaten Berau. Menganalisis pengaruh luas hutan produksi secara signifikan terhadap pertumbuhan ekonomi sektor Kehutanan di Kabupaten Berau. Menganalisis pengaruh pertumbuhan ekonomi sektor Kehutanan secara signifikan terhadap kesempatan kerja di Kabupaten Berau.
\end{abstract}

Kata Kunci: Tenaga kerja subsektor kehutanan; investasi pemerintah

\section{Factors affecting the economic growth of the forestry sector and its impact on employment}

\begin{abstract}
Research aimed to analyze the influence of labor forestry subsector significantly to economic growth of the forestry sector in Berau. Analyze the effects of the forestry sector Government Investment significantly to economic growth of the forestry sector in Berau. Analyze the influence of the forest area of production significantly to economic growth of the forestry sector in Berau. Analyze the effect of economic growth significantly forestry sector on employment in Berau.
\end{abstract}

Keywords: Labor subsector forestry; government investment 


\section{PENDAHULUAN}

Pembangunan bidang kehutanan merupakan bagian integral dari pembangunan nasional, sehingga jelaslah bahwa pembangunan kehutanan merupakan tanggung jawab bersama, dilakukan secara bertanggung jawab dan transparan serta diselenggarakan untuk menuju pengelolaan hutan yang lestari guna memberi manfaat bagi rakyat. Oleh karena itu praktek pengelolaan sumber daya hutan harus tetap memperhatikan aspek ekologi, ekonomi dan sosial budaya, sehingga pemanfaatan sumber daya hutan yang kelihatannya menjadi sarana ekonomi utama dari penyelenggaraan desentralisasi dapat lebih memperhatikan aspek ketatalaksanaan sumber daya hutan sebagai penyokong kehidupan manusia antar generasi

Pengendalian tebangan dari hutan alam atas dasar volume dalam sistem Tebang Pilih Tanam Indonesia (TPTI) dipandang masih memiliki beberapa kelemahan, maka dalam rangka peningkatan pengendalian tebangan dari hutan alam dalam sistem TPTI perlu didasarkan pada luas dan jumlah pohon tebangan, sesuai dengan Keputusan Menteri Kehutanan Nomor : 143/Kpts-II/1998 tanggal 25 Februari 1998, tentang Penetapan Target Produksi Tebangan Tahunan Pengusahaan Hutan Alam. Pada Bab I Pasal 1 dijelaskan bahwa Penetapan target produksi tebangan tahunan didasarkan atas hasil Inventarisasi Tegakan Sebelum Penebangan (ITSP) dan luas virgin forest yang ada atau luas hutan yang belum pernah ditebang dalam siklus yang bersangkutan atau target tebangan ditentukan berdasarkan luas tebangan dan dan jumlah pohon pada setiap petak tebangan dengan batas diameter yang diijinkan ditebang sesuai ketentuan, sedangkan perhitungan volumenya merupakan penjumlahan volume semua pohon yang diijinkan ditebang pada setiap petak tebangan dikalikan dengan faktor Eksploitasi $(0,8)$ dan faktor keamanan $(0,7)$. Penentuan akhir dari Jatah Tebangan Tahunan yang direkomendasikan oleh Dinas Kehutanan Propinsi Kalimantan Timur selain dihitung berdasarkan perhitingan AAC (SK Menhut No. 143/Kpts-II/1998 tanggal 25 Februari 1998) dinilai pula Kinerja/perfomance HPH, kemampuan alat (peralatan) dan proposal Rencana Karya Lima Tahun.

Sumberdaya hutan memiliki kedudukan, fungsi dan peran nyata bagi setiap umat dunia Internasional. Hutan merupakan sumberdaya hutan yang dapat memulihkan diri selama pemanfaatannya tidak melampaui daya pulihnya, sehingga manfaat ganda dari hutan akan terus mengalir selama keberadaan dan fungsinya tetap terjamin. Adanya pergeseran paradigma pembangunan kehutanan, perlu secara tegas pengaturan prinsip hubungan negara dan masyarakat, hubungan ekonomi dan ekologi dan hubungan manusia dan biosfir, agar keseimbangan antara kepentingan ekonomi dan ekologi untuk menciptakan keberlanjutan kehidupan serta manusia dan biosfir merupakan kesatuan dalam alam melalui interaksi yang sinergis.

Langkah menuju pengelolaan hutan oleh masyarakat yang mandiri perlu persiapan serius. Persoalannya pengelolaan hutan yang lestari memerlukan penguasaan tehnik silvyculture yang baik disamping modal dan kemampuan manajemen. Kearifan tradisional yang sudah dimiliki masyarakat dijadikan asset untuk dikembangkan dan diintegrasikan dengan sistem agribisnis dengan tetap memegang teguh prinsip maximum and sustained principle, berkeadilan dan berkelanjutan. Pemberdayaan masyarakat setempat dalam pemanfaatan hutan, langkah yang dilakukan adalah antara lain membangun kelompok atau unit organisasi dalam suatu wadah untuk semua kepentingan anggota masyarakatnya. Kelompok ini dibangun anggotanya sendiri, dibimbing atau difasilitasi pemerintah atau lembaga lain, sehingga mandiri dan solid. Hanya dengan kekuatan dan kemampuan kelompok sustainable forest dapat diwujudkan kesejahteraan anggota masyarakat.

Sumberdaya hutan mulai dimanfaatkan secara ekonomis untuk pembangunan nasional sejak dikeluarkannya Undang-Undang Nomor 1 Tahun 1967 yang mengatur tentang Penanaman Modal Asing dan Undang- Undang Nomor 6 Tahun 1968 mengenai Penanaman Modal Dalam Negeri. Selanjutnya lahir juga Undang-Undang Nomor 5 Tahun 1967 tentang Undang-Undang Pokok Kehutanan yang mampu meningkatkan laju pertumbuhan ekonomi nasional, yang bersanding dengan Undang-Undang Nomor 1 Tahun 1967 dan UndangUndang Nomor 6 Tahun 1968. Implementasinya, lahirlah Peraturan Pemerintah Nomor 21 Tahun 1970 tentang Hak Pengusahaan Hutan dan Hak Pemungutan Hasil Hutan serta berbagai insentif ekonomi dalam pengusahaan hutan sehingga merangsang tumbuhnya usaha bidang kehutanan khususnya dalam bentuk HPH di Indonesia. 
Dari situ banyak keuntungan ekonomi yang dihasilkan oleh sektor kehutanan Indonesia melalui sektor kehutanan merupakan produsen kayu lapis dunia yang layak diperhitungkan, bahkan sejak tahun 1988 pangsa pasar produk kayu lapis Indonesia telah menguasai hampir $50 \%$ kayu lapis dunia dan menempatkan Indonesia sebagai pimpinan pasar yang sangat tangguh (Nurrokhmat, 2008). Sedangkan dalam konteks pemanfaatan hasil hutan bukan kayu (HHBK), terdapat beberapa jenis produk yang merupakan komoditas penting perdagangan seperti terpentin, gondorukem/getah damar, jelutung, tengkawang, kemiri, sutera alam, gaharu, sarang burung wallet, berbagai jenis tanaman obat dan rempah, serta berbagai jenis lain komoditi perdagangan baik di dalam negeri maupun ekspor.

Meskipun sektor kehutanan memberikan sumbangan pada devisa negara cukup signifikan, namun hal ini tidak diikuti dengan perkembangan peningkatan PDB dari sektor kehutanan yang hanya 1,2\% selama 10 tahun terakhir. Jika dilihat dari data BPS, kontribusi pertumbuhan ekonomi sektor kehutanan terhadap perekonomian menyeluruh yang ditunjukkan dari PDB nasional relatif kecil. Dalam perhitungan PDB, kehutanan dimasukkan sebagai salah satu subsektor perekonomian dari sektor pertanian. Sebagai bagian dari sektor pertanian, dalam periode tersebut kehutanan menyumbang sekitar $10,01 \%$ per tahun kepada pembentukan PDB pertanian. Sektor pertanian sendiri menyumbang rata-rata $16,15 \%$ per tahun kepada pembentukan PDB nasional. (Suhermanto, 2009).

Seharusnya dalam melihat share kehutanan terhadap perekonoman nasional jangan hanya melihat dari nilai kontribusi terhadap pembentukan PDB saja, namun harus memperhatikan juga multiplier effect sektor tersebut baik terhadap output, pendapatan dan tenaga kerja, serta harus dilihat pula nilai keterkaitan sektor kehutanan terhadap sektor-sektor produksi lainnya. Selama ini sistem yang dianut dalam perhitungan PDB sub-sektor kehutanan hanyalah kegiatan sektor hulu dan industri primer pengolahan hasil hutan sementara sektor hilir dan industri pengolahan lanjutannya tidak termasuk nilai tambah yang diperhitungkan dalam sub-sektor kehutanan sehingga masih belum menggambarkan kontribusi riil sektor kehutanan terhadap penerimaan negara. Selain itu kajian yang selalu dilakukan lebih berfokus pada peranan suatu sektor secara parsial. Padahal ada keterkaitan dari output dari sektor kehutanan yang digunakan sebagai input oleh sektor-sektor ekonomi lainnya dalam proses produksi. Dengan demikian penting pula untuk diketahui bagaimana posisi sektor kehutanan secara riil pada proses produksi dalam penciptaan output, tenaga kerja dan nilai tambah dalam kurun waktu

1995-2008, mengingat pada periode tersebut perekonomian Indonesia cukup mengalami fluktuasi dengan adanya krisis ekonomi 1997, keruntuhan regim orde baru, perubahan paradigma pembangunan dari sentralistik ke desentralisasi melalui penetapan otonomi daerah serta reformasi pembangunan di segala bidang, tak terkecuali sektor kehutanan. Disisi lain, kondisi hutan Indonesia yang telah mengalami eksploitasi besar-besaran pada tahun-tahun sebelumnya sehingga menghasilkan deforestasi dan degradasi lingkungan yang cukup parah, menarik untuk dikaji apakah mempengaruhi kinerja sektor kehutanan dalam perekonomian nasional. Berbicara masalah pengelolaan hutan secara ekonomi tidak terlepas dari peran serta Modal Pemerintah dan Swasta serta penyediaan Tenaga Kerja yang bergerak langsung dalam Proses Pengelolaan Hasil Hutan tersebut. Kegiatan ini meliputi penebangan dan pemotongan segala jenis kayu, pengambilan hasil Hutan dan Perburuan Binatang Liar yang meliputi Kayu Bundar, Rotan, Damar, Sarang Burung, kulit reptil dan hasil Hutan Lainnya.

\section{METODE}

\section{Variabel Penelitian Dan Definisi Operasional}

Variabel penelitian adalah segala sesuatu yang akan menjadi objek penelitian, sedangkan definisi operasional adalah suatu definisi yang diberikan kepada suatu variabel dengan memberikan arti. Jadi penelitian ini meliputi faktor-faktor yang berperan dalam peristiwa atau gejala yang akan diteliti.

Dalam penelitian yang dilakukan ini digunakan dua jenis variabel penelitian, yaitu variabel dependen atau variabel tak bebas (dependent variable) dan variabel independen atau variabel bebas (independent variable).

1) Kesempatan kerja Kabupaten Berau (Y2)

Kesempatan kerja adalah suatu keadaan yang menggambarkan ketersediaan pekerjaan untuk diisi oleh para pencari kerja. Namun bisa diartikan juga sebagai permintaan atas tenaga kerja. Kesempatan kerja dalam penelitian ini adalah jumlah seluruh penduduk kabupaten Berau yang 
sudah memasuki pasar kerja atau dengan kata lain penduduk yang sudah bekerja (dalam satuan jiwa).

2) Pertumbuhan Ekonomi Subsektor Kehutanan (Y1)

Pertumbuhan ekonomi adalah proses perubahan kondisi perekonomian suatu negara secara berkesinambungan menuju keadaan yang lebih baik selama periode tertentu. Pertumbuhan ekonomi dapat diartikan juga sebagai proses kenaikan kapasitas produksi suatu perekonomian yang diwujudkan dalam bentuk kenaikan pendapatan nasional. Variabel Pertumbuhan Ekonomi Subsektor Kehutanan yang digunakan adalah PDRB riil sub sektor Kehutanan di Kabupaten Berau berdasarkan harga konstan tahun 2000 yang dinyatakan dalam satuan juta rupiah pada tahun 2002 sampai dengan tahun 2014.

3) Jumlah Tenaga Kerja (X1)

Tenaga kerja adalah setiap orang yang mampu melakukan pekerjaan guna menghasilkan barang atau jasa untuk memenuhi kebutuhan sendiri maupun masyarakat. Jumlah Tenaga Kerja (Penyerapan Kerja) adalah tenaga kerja yang terserap di sub sektor Kehutanan di Kabupaten Berau sejak tahun 2002 sampai dengan tahun 2014.

4) Investasi Pemerintah (X2)

Investasi Pemerintah adalah penempatan sejumlah dana dan/atau barang oleh pemerintah pusat dalam jangka panjang untuk investasi pembelian surat berharga dan investasi langsung, yang mampu mengembalikan nilai pokok ditambah dengan manfaat ekonomi, sosial, dan/atau manfaat lainnya dalam jangka waktu tertentu. Pengeluaran pembangunan sektor kehutanan oleh Pemerintah Kabupaten Malianu yang merupakan akumulasi setiap tahunnya sejak tahun 2002 hingga tahun 2014 yang berasal dari dana APBD yang diukur dalam satuan rupiah.

5) Luas Hutan Produksi (X3)

Luas hutan produksi adalah areal hutan yang sengaja dipertahankan sebagai kawasan hutan dan berfungsi untuk menghasilkan atau memproduksi hasil hutan bagi kepentingan masyarakat, dibidang industri dan ekspor. Hutan ini ditentukan dengan batas-batas suatu HPH (Hak Penguasaan Hutan) dan dikelola untuk menghasilkan kayu. Luas hutan produksi merupakan luasan areal hutan yang sengaja dipertahankan sebagai kawasan hutan dan berfungsi untuk menghasilkan atau memproduksi hasil hutan bagi kepentingan masyarakat, dibidang industri dan ekspor dalam satuan Ha.

\section{Jenis Data Dan Sumber Data}

Dalam penelitian yang dilakukan ini menggunakan sumber data sekunder yang didapatkan melalui studi literatur baik dari buku, jurnal, penelitian, serta sumber data terbitan beberapa instansi tertentu. Data yang digunakan dikumpulkan secara runtut waktu (time series) dari tahun 2002 hingga tahun 2014. Data-data yang diperlukan dalam penelitian ini antara lain adalah:

a) Data mengenai besarnya kesempatan kerja Kabupaten Berau periode waktu tahun tahun 2002 hingga tahun 2014.

b) Data mengenai besarnya pertumbuhan ekonomi sektor kehutanan periode waktu tahun tahun 2002 hingga tahun 2014.

c) Data mengenai jumlah tenaga kerja pada subsektor kehutanan di Kabupaten Berau pada periode tahun tahun 2002 hingga tahun 2014.

d) Data mengenai besarnya investasi pemerintah Kabupaten Berau pada subsektor kehutanan tahun 2002 hingga tahun 2014.

e) Data mengenai luasan hutan produksi di kabupaten Berau pada tahun 2002 hingga tahun 2014.

\section{Metode Pengumpulan Data}

Pengumpulan data dilakukan dengan dokumentasi, yaitu mengumpulkan catatan atau data yang diperlukan sesuai penelitian yang akan dilakukan dari dinas/kantor/instansi atau lembaga terkait. Data yang akan dikumpulkan diperoleh dari dinas/lembaga/kantor seperti Badan Pusat Statistik (BPS) Kabupaten Berau dan Dinas Kehutanan Kabupaten Berau. 


\section{HASIL DAN PEMBAHASAN}

\section{Analisis Jalur Substruktur Pertama}

Persamaan substuktur pertama dengan penjabaran sebagai berikut :

Keterangan:

$\mathrm{Y} 1=$ pertumbuhan sektor kehutanan

$\mathrm{X} 1=$ tenaga kerja subsektor kehutanan

$\mathrm{X} 2$ = investasi pemerintah

$\mathrm{X} 3=$ luas hutan produksi

$\mathrm{E} 1=$ error kesatu

Analisis jalur substruktur pertama ini digunakan untuk menguji pengaruh tenaga kerja subsektor kehutanan, investasi pemerintah, luas hutan produksi terhadap pertumbuhan ekonomi sektor kehutanan.

Penyelesaian model dilakukan dengan bantuan Program SPSS for Windows Release 22.0. Adapun hasilnya adalah sebagai berikut:

Tabel 1. Hasil Analisis Jalur X1, X2, X3, Y1.

\begin{tabular}{|c|c|c|c|c|c|c|}
\hline & \multicolumn{2}{|c|}{$\begin{array}{l}\text { Unstandardized } \\
\text { Coefficients }\end{array}$} & \multirow{2}{*}{$\begin{array}{c}\begin{array}{c}\text { Standardize d } \\
\text { Coefficients }\end{array} \\
\text { Beta }\end{array}$} & & & \\
\hline & B & Std. Error & & & & \\
\hline 1 (Constant) &,- 074 & 1,280 & & &,- 057 & ,955 \\
\hline $\mathrm{X} 1$ & ,000 & 000 & & ,298 & 2,764 & ,022 \\
\hline $\mathrm{X} 2$ & $-1,004 \mathrm{E}-08$ & ,000 &,- 001 & &,- 003 & ,998 \\
\hline $\mathrm{X} 3$ & $5,367 \mathrm{E}-06$ &, 000 & & ,714 & 2,093 & ,066 \\
\hline
\end{tabular}

Sumber: Data diolah

Dari hasil analisis di atas, maka dapat disusun persamaan sebagai berikut: $\mathrm{Y} 1=0,298 \mathrm{X} 1-0.001$ $\mathrm{X} 2+0.714 \mathrm{X} 3+\mathrm{E}$

Persamaan menunjukkan bahwa tenaga kerja subsektor kehutanan, investasi pemerintah, luas hutan produksi terhadap pertumbuhan ekonomi sektor kehutanan. Jadi, setiap perubahan variabel eksogen akan berpengaruh terhadap variabel endogen.

Berdasarkan tabel 1 tersebut dapat diketahui nilai signifikansi masing-masing variabel dengan penjelasan sebagai berikut:

a) Nilai signifikansi variabel tenaga kerja subsektor kehutanan (X1) sebesar 0.022 dimana nilai tersebut lebih kecil dari $0.10(0.022<0.10)$ sehingga dapat disimpulkan bahwa variabel tenaga kerja subsektor kehutanan (X1) berpengaruh signifikan terhadap variabel pertumbuhan ekonomi sektor kehutanan (Y1).

b) Nilai signifikansi variabel investasi pemerintah (X2) sebesar 0.998 dimana nilai tersebut lebih besar dari $0.10(0.998>0.10)$ sehingga dapat disimpulkan bahwa variabel investasi pemerintah (X2) berpengaruh tidak nsignifikan terhadap variabel pertumbuhan ekonomi sektor kehutanan (Y1).

c) Nilai signifikansi variabel luas hutan produksi (X3) sebesar 0.066 dimana nilai tersebut lebih besar dari $0.10(0.066<0.10)$ sehingga dapat disimpulkan bahwa variabel luas hutan produksi $(\mathrm{X} 3)$ berpengaruh signifikan terhadap variabel pertumbuhan ekonomi sektor kehutanan (Y1).

Setelah mengetahui nilai koefisien maka selanjutnya untuk mengetahui keeratan hubungan antara variabel eksogen terhadap variabel endogen dapat dilihat dari nilai koefisien kolerasi (R) pada tabel berikut:

Tabel 2. Hasil Analisis Koefisien Korelasi (R).

\begin{tabular}{|c|c|c|c|c|}
\hline Model & $\mathrm{R}$ & R Square & $\begin{array}{l}\text { Adjusted R } \\
\text { Square }\end{array}$ & $\begin{array}{l}\text { Std. Error of the } \\
\text { Estimate }\end{array}$ \\
\hline 1 & ,992a & ,985 & ,979 & , 10179 \\
\hline
\end{tabular}


Berdasarkan hasil data didapatkan nilai koefisien korelasi sebesar 0.992. Hal ini berarti terdapat hubungan antara variabel tenaga kerja subsector kehutanan, investasi pemerintah, luas hutan produksi terhadap pertumbuhan ekonomi sektor kehutanan dengan tingkat hubungan sangat kuat karena berada diinterval koefisien 0.800-1.000.

Analisis koefisien determinasi digunakan untuk menunjukkan proporsi variabel endogen yang dijelaskan oleh variabel eksogen. R2 mampu memberikan informasi mengenai variasi nilai variabel endogen yang dapat dijelaskan oleh model yang digunakan. Apabila R2 mendekati angka satu berarti terdapat hubungan yang kuat. Koefisien determinasi (R2) sebesar 0.985 artinya bahwa $98.50 \%$ variasi dari variabel pertumbuhan sektor kehutanan dapat dijelaskan oleh variabel tenaga kerja subsektor kehutanan, investasi pemerintah, luas hutan produksi, sedangkan 1.50\% lainnya dijelaskan oleh variabel lain yang tidak masuk dalam variabel yang diteliti.

Pengujian ini untuk mengetahui adanya pengaruh tenaga kerja subsektor kehutanan, investasi pemerintah, luas hutan produksi terhadap pertumbuhan ekonomi sektor kehutanan secara bersamaan. Hasil pengujian F sebagai berikut:

Tabel 3. Hasil Analisis Uji F (Uji Simultan).

\begin{tabular}{lrrrrr}
\hline Model & $\begin{array}{c}\text { Sum of } \\
\text { Squares }\end{array}$ & df & $\begin{array}{c}\text { Mean } \\
\text { Square }\end{array}$ & F & Sig. \\
\hline 1 Regression & 5,941 & 3 & 1,980 & 191,146 &, 000 \\
Residual Total &, 093 & 9 &, 010 & & \\
& 6,034 & 12 & & & \\
\hline
\end{tabular}

a. Predictors: (Constant), X3, X2, X1

b. Dependent Variable: Y1

Sumber: Data diolah

Tabel tersebut menunjukkan bahwa secara keseluruhan nilai Fhitung sebesar 191,146 dimana nilai tersebut lebih besar di bandingkan dengan Ftabel 3.97 (Df1 = 5 dan Df2 $=7$ (n-k-1 / 13-5-1)). pada taraf signifikan $(\alpha) 10 \%$ pada tabel ANOVA terlihat nilai signifikansi 0.000 untuk seluruh variabel dimana nilai tersebut lebih kecil dibandingkan taraf signifikan $(\alpha)$ 10\% dengan demikian dapat diambil kesimpulan bahwa secara bersama-sama tenaga kerja subsektor kehutanan, investasi pemerintah, luas hutan produksi berpengaruh signfikan terhadap pertumbuhan ekonomi sektor kehutanan.

Uji parsial ini digunakan untuk mengetahui besarnya pengaruh variabel tenaga kerja subsektor kehutanan, investasi pemerintah, luas hutan produksi terhadap pertumbuhan ekonomi sektor kehutanan secara individual. Hasil pengujian uji parsial sebagai berikut:

Tabel 4. Hasil Analisis Uji t (Uji Parsial).

\begin{tabular}{|c|c|c|c|c|c|}
\hline \multirow[b]{2}{*}{ Model } & \multicolumn{2}{|c|}{$\begin{array}{c}\text { Unstandardized } \\
\text { Coefficients }\end{array}$} & \multirow{2}{*}{$\begin{array}{c}\text { Standardize d } \\
\text { Coefficients } \\
\text { Beta }\end{array}$} & \multirow[b]{2}{*}{$\mathrm{t}$} & \multirow[b]{2}{*}{ Sig. } \\
\hline & B & Std. Error & & & \\
\hline 1 (Constant) &,- 074 & 1,280 & &,- 057 & ,955 \\
\hline $\mathrm{X} 1$ &, 000 & ,000 & ,298 & 2,764 &, 022 \\
\hline $\mathrm{X} 2$ & -1,004E-08 &, 000 &,- 001 &,- 003 & ,998 \\
\hline X3 & 5,367E-06 &, 000 &, 714 & 2,093 & ,066 \\
\hline
\end{tabular}

Sumber: Data diolah

Tabel tersebut dapat dijelaskan sebagai berikut:

1) Pada level of significant 0.10 , diperoleh signifikansi untuk variabel tenaga kerja subsektor kehutanan, sebesar $0.022<0.10$, atau diperoleh thitung untuk variabel tenaga kerja subsektor kehutanan (X1), sebesar 2,764, nilai tersebut lebih besar dibandingkan ttabel $1.89(\mathrm{Pr}=0.05$ dan 
Df2 $=7$ (n-k-1/13-5-1)) Dengan demikian variabel tenaga kerja subsektor kehutanan terbukti secara statistik berpengaruh signifikan terhadap variabel pertumbuhan sektor kehutanan.

2) Pada level of significant 0.10 , diperoleh signifikansi untuk variabel investasi pemerintah, sebesar $0.998>0.10$, atau diperoleh thitung untuk variabel investasi pemerintah (X2), sebesar 0,003, nilai tersebut lebih kecil dibandingkan ttabel $1.89(\operatorname{Pr}=0.05$ dan Df2 $=7$ (n-k-1 / 13-5-1)) Dengan demikian variabel investasi pemerintah terbukti secara statistik berpengaruh tidak signifikan terhadap variabel pertumbuhan sektor kehutanan.

3) Pada level of significant 0.10 , diperoleh signifikansi untuk variabel luas hutan produksi, sebesar $0.066<0.10$, atau diperoleh thitung untuk variabel luas hutan produksi (X3), sebesar 2,093, nilai tersebut lebih besar dibandingkan ttabel $1.89(\mathrm{Pr}=0.05$ dan Df2 $=7(\mathrm{n}-\mathrm{k}-1 / 13-5-1))$ Dengan demikian variabel luas hutan produksi terbukti secara statistik berpengaruh signifikan terhadap variabel pertumbuhan sektor kehutanan.

\section{Analisis Jalur Substruktur Kedua}

Persamaan substuktur kedua adalah sebagai berikut :

Keterangan :

$\mathrm{Y} 2$ = kesempatan kerja

$\mathrm{Y} 1=$ pertumbuhan sektor kehutanan

$\mathrm{X} 1=$ tenaga kerja subsektor kehutanan

$\mathrm{X} 2$ = investasi pemerintah

$\mathrm{X} 3=$ luas hutan produksi

$\mathrm{E} 2$ = error kedua

Analisis jalur dalam substruktur kedua untuk mengetahui pengaruh tenaga kerja subsektor kehutanan (X1), investasi pemerintah (X2) dan luas hutan produksi (X3) secara langsung terhadap kesempatan kerja dan untuk mengetahui pengaruh secara tidak langsung terhadap kesempatan kerja melalui pertumbuhan sektor kehutanan. Penyelesaian model dilakukan dengan bantuan Program SPSS for Windows Release 22.0 dan perhitungan selengkapnya dapat dilihat pada Lampiran, dengan analisis masing-masing pengaruh sebagai berikut:

Tabel 5. Hasil Analisis Jalur X1, X2, X3, Y1 dan Y2.

\begin{tabular}{|c|c|c|c|c|c|}
\hline \multirow[b]{2}{*}{ Model } & \multicolumn{2}{|c|}{$\begin{array}{l}\text { Unstandardized } \\
\text { Coefficients }\end{array}$} & \multicolumn{3}{|l|}{$\begin{array}{r}\text { Standardized } \\
\text { Coefficients }\end{array}$} \\
\hline & B & $\begin{array}{l}\text { Std. } \\
\text { Error }\end{array}$ & Beta & $\mathrm{t}$ & Sig. \\
\hline 1 (Constant) & 574,580 & 774,199 & & ,742 & ,479 \\
\hline $\mathrm{X} 1$ &, 176 &, 034 & 1,442 & 5,165 & ,001 \\
\hline $\mathrm{X} 2$ & ,000 & ,002 & ,027 & ,049 & ,962 \\
\hline $\mathrm{X} 3$ &,- 001 &, 002 &,- 355 &,- 449 &, 665 \\
\hline Y1 & $-62,868$ & 201,595 &,- 198 &,- 312 &, 763 \\
\hline
\end{tabular}

Sumber: Data diolah

Dari hasil analisis di atas, maka dapat disusun persamaan sebagai berikut: $\mathrm{Y} 2=1,442 \mathrm{X} 1+0.027$ $\mathrm{X} 2-0,355 \mathrm{X} 3-0,198 \mathrm{Y} 1$ + E Persamaan menunjukkan bahwa indeks pembangunan manusia dipengaruhi oleh tenaga kerja subsektor kehutanan (X1), investasi pemerintah (X2) dan luas hutan produksi (X3) dan pertumbuhan sektor kehutanan (Y1). Jadi, setiap perubahan variabel tenaga kerja subsektor kehutanan (X1), investasi pemerintah (X2) dan luas hutan produksi (X3) dan pertumbuhan sektor kehutanan (Y1) akan berpengaruh terhadap variabel kesempatan kerja.

Berdasarkan tabel 5 tersebut dapat diketahui nilai signifikansi masing-masing variabel dengan penjelasan sebagai berikut:

1) Nilai signifikansi variabel tenaga kerja subsektor kehutanan (X1) sebesar 0.001 dimana nilai tersebut lebih kecil dari $0.10(0.001<0.10)$ atau diperoleh thitung untuk variabel tenaga kerja subsektor kehutanan (X1), sebesar 5,165, nilai tersebut lebih besar dibandingkan ttabel 
$1.89(\operatorname{Pr}=0.05$ dan Df2 = 7 (n-k-1 / 13-5-1)) sehingga dapat disimpulkan bahwa variabel tenaga kerja subsektor kehutanan (X1) berpengaruh signifikan terhadap variabel kesempatan kerja (Y2).

2) Nilai signifikansi variabel investasi pemerintah (X2) sebesar 0.962 dimana nilai tersebut lebih besar dari $0.10(0.962>0.10)$, atau diperoleh thitung untuk variabel investasi pemerintah (X2), sebesar 0,049, nilai tersebut lebih kecil dibandingkan ttabel $1.89(\operatorname{Pr}=0.05$ dan Df2 $=7$ (nk-1 / 13-5-1)) sehingga dapat disimpulkan bahwa variabel investasi pemerintah (X2) berpengaruh tidak signifikan terhadap variabel kesempatan kerja (Y2).

3) Nilai signifikansi variabel luas hutan produksi (X3) sebesar 0.665 dimana nilai tersebut lebih besar dari $0.10(0.665>0.10)$ atau diperoleh thitung untuk variabel luas hutan produksi $(\mathrm{X} 3)$, sebesar - 0,449, nilai tersebut lebih kecil dibandingkan ttabel $1.89(\mathrm{Pr}=0.05$ dan Df2 $=7(\mathrm{n}-\mathrm{k}-1 /$ 13-5-1)) sehingga dapat disimpulkan bahwa variabel luas hutan produksi (X3) berpengaruh tidak signifikan terhadap variabel kesempatan kerja (Y2).

Nilai signifikansi variabel pertumbuhan sektor kehutanan (Y1) sebesar 0.763 dimana nilai tersebut lebih besar dari $0.10(0.763>0.10)$ atau diperoleh thitung untuk variabel pertumbuhan sektor kehutanan (Y1), sebesar -0,314, nilai tersebut lebih kecil dibandingkan ttabel $1.89(\mathrm{Pr}=0.05$ dan Df2 = 7 (n-k-1 / 13-5-1)) sehingga dapat disimpulkan bahwa variabel pertumbuhan sektor kehutanan (Y1) berpengaruh tidak signifikan terhadap variabel kesempatan kerja (Y2). Setelah mengetahui nilai koefisien, maka selanjutnya untuk mengetahui keeratan hubungan antara variabel eksogen dan endogen dapat dilihat dari nilai koefisien kolerasi (R) pada tabel berikut:

Tabel 6. Hasil Analisis Koefisien Korelasi (R)

\begin{tabular}{lcccc}
\hline Model & R & R Square & Adjusted R Square & $\begin{array}{c}\text { Std. Error of the } \\
\text { Estimate }\end{array}$ \\
\hline 1 &, $975 \mathrm{a}$ &, 950 &, 925 & 61,55884 \\
\hline Sumber: Data diolah & & & &
\end{tabular}

Sumber: Data diolah

Berdasarkan hasil data didapatkan nilai koefisien korelasi sebesar 0,975. Hal ini berarti terdapat hubungan antara variabel tenaga kerja subsektor kehutanan (X1), investasi pemerintah (X2) dan luas hutan produksi (X3) dan pertumbuhan sektor kehutanan (Y1) terhadap variabel kesempatan kerja (Y2) dengan tingkat hubungan sangat kuat karena berada diinterval koefisien 0.800-1.000.

Analisis koefisien determinasi digunakan untuk menunjukkan proporsi variabel endogen yang dijelaskan oleh variabel eksogen. R2 mampu memberikan informasi mengenai variasi nilai variabel endogen yang dapat dijelaskan oleh model regresi yang digunakan. Apabila R2 mendekati angka satu berarti terdapat hubungan yang kuat. Koefisien determinasi (R2) sebesar 0,950 artinya bahwa 95\% variasi dari variabel kesempatan kerja dapat dijelaskan oleh variabel tenaga kerja subsektor kehutanan (X1), investasi pemerintah (X2) dan luas hutan produksi (X3) dan pertumbuhan sektor kehutanan (Y1), sedangkan 5\% lainnya dijelaskan oleh variabel lain yang tidak masuk dalam variabel yang diteliti.

Pengujian ini untuk mengetahui adanya pengaruh tenaga kerja subsektor kehutanan (X1), investasi pemerintah (X2) dan luas hutan produksi (X3) dan pertumbuhan sektor kehutanan (Y1) dengan kesempatan kerja secara bersamaan. Hasil pengujian F sebagai berikut:

Tabel 7. Hasil Analisis Uji F (Uji Simultan)

\begin{tabular}{|c|c|c|c|c|c|}
\hline Model & $\begin{array}{r}\text { Sum of } \\
\text { Squares }\end{array}$ & Df & $\begin{array}{l}\text { Mean } \\
\text { Square }\end{array}$ & $\mathrm{F}$ & Sig. \\
\hline \multirow{3}{*}{$\begin{array}{l}\text { 1 Regression } \\
\text { Residual Total }\end{array}$} & 579477,155 & 4 & 144869,289 & 38,229 & ,000 \\
\hline & 30315,922 & 8 & 3789,490 & & \\
\hline & 609793,077 & 12 & & & \\
\hline
\end{tabular}

a. Predictors: (Constant), Y1, X2, X1, X3

b. Dependent Variable: Y2

Sumber: Data diolah 
Tabel di atas menunjukkan bahwa secara keseluruhan nilai Fhitung sebesar 38,229 dimana nilai tersebut lebih besar di bandingkan dengan Ftabel 3.97 (Df1 = 5 dan Df2 $=7$ (n-k-1 / 13-5-1)). pada taraf signifikan $(\alpha)$ 10\% pada tabel ANOVA terlihat nilai signifikansi 0.000 untuk seluruh variabel dimana nilai tersebut lebih kecil dibandingkan taraf signifikan $(\alpha) \quad 10 \%$ dengan demikian dapat diambil kesimpulan bahwa secara bersama-sama tenaga kerja subsektor kehutanan (X1), investasi pemerintah (X2) dan luas hutan produksi (X3) dan pertumbuhan sektor kehutanan (Y1) berpengaruh secara signifikan terhadap indeks pembangunan manusia.

Uji parsial ini digunakan untuk mengetahui besarnya pengaruh variabel tenaga kerja subsektor kehutanan (X1), investasi pemerintah (X2) dan luas hutan produksi (X3) dan pertumbuhan sektor kehutanan (Y1) dengan kesempatan kerja secara individual. Hasil pengujian uji parsial sebagai berikut:

Tabel 8. Hasil Analisis Uji t (Uji Parsial).

\begin{tabular}{lrrrrr}
\hline \multicolumn{7}{c}{$\begin{array}{c}\text { Unstandardized } \\
\text { Coefficients }\end{array}$} & \multicolumn{2}{c}{$\begin{array}{c}\text { Standardized } \\
\text { Coefficients }\end{array}$} & & \\
Model & \multicolumn{1}{c}{$\begin{array}{c}\text { Std. } \\
\text { Error }\end{array}$} & \multicolumn{1}{c}{ Beta } & \multicolumn{1}{c}{ t } & \multicolumn{1}{c}{ Sig. } \\
\hline 1 (Constant) & 574,580 & \multicolumn{1}{c}{774,199} & &, 742 &, 479 \\
X1 &, 176 &, 034 & 1,442 & 5,165 &, 001 \\
X2 &, 000 &, 002 &, 027 &, 049 &, 962 \\
X3 &,- 001 &, 002 &,- 355 &,- 449 &, 665 \\
Y1 & $-62,868$ & 201,595 &,- 198 &,- 312 &, 763 \\
\hline
\end{tabular}

Sumber: Lampiran Data diolah

Tabel diatas dapat dijelaskan sebagai berikut:

1) Pada level of significant 0.10 , diperoleh signifikansi untuk variabel tenaga kerja subsektor kehutanan, sebesar $0.001<0.10$, atau

2) diperoleh thitung untuk variabel tenaga kerja subsektor kehutanan (X1), sebesar 5,165, Dengan demikian variabel tenaga kerja subsektor kehutanan terbukti secara statistik berpengaruh signifikan terhadap variabel kesempatan kerja.

3) Pada level of significant 0.10 , diperoleh signifikansi untuk variabel investasi pemerintah, sebesar $0.962>0.10$, atau diperoleh thitung untuk variabel investasi pemerintah (X2), sebesar 0,049, Dengan demikian variabel investasi pemerintah terbukti secara statistik berpengaruh tidak signifikan terhadap variabel kesempatan kerja.

4) Pada level of significant 0.10 , diperoleh signifikansi untuk variabel luas hutan produksi, sebesar $0.665>0.10$, atau diperoleh thitung untuk variabel luas hutan produksi (X3), sebesar -0,449, Dengan demikian variabel luas hutan produksi terbukti secara statistik berpengaruh tidak signifikan terhadap variabel kesempatan kerja.

5) Pada level of significant 0.10 , diperoleh signifikansi untuk variabel pertumbuhan sektor kehutanan, sebesar $0.763>0.10$, atau diperoleh thitung untuk variabel pertumbuhan sektor kehutanan (Y1), sebesar -0,312, Dengan demikian variabel luas hutan produksi terbukti secara statistik berpengaruh signifikan terhadap variabel kesempatan kerja. berikut:

Jadi dapat diketahui dari analisis diatas model persamaan analisis untuk dua jalur adalah sebagai

Untuk persamaan substruktur pertama :

$\mathrm{Y} 1=0,298 \mathrm{X} 1-0.001 \mathrm{X} 2+0.714 \mathrm{X} 3+0.015$, Dimana: $\mathrm{E} 1=1-\mathrm{R}$ square $=1-0.985=0,015$ Untuk persamaan substruktur kedua:

$\mathrm{Y} 2=1,442 \mathrm{X} 1+0.027 \mathrm{X} 2-0,355 \mathrm{X} 3-0,198 \mathrm{Y} 1+0.05$, Dimana: $\mathrm{E} 1=1-\mathrm{R}$ square $=1-$ $0.950=0,05$

Berdasarkan penjabaran tersebut maka diperoleh keterangan mengenai pengaruh langsung, pengaruh tidak langsung dan pengaruh total yang dapat dilihat pada tabel dibawah ini:

Tabel 5.13: Pengaruh Langsung 


\begin{tabular}{ccc}
\hline \multirow{2}{*}{ No } & \multicolumn{2}{c}{ Direct Effect } \\
\cline { 2 - 3 } & Variabel & Nilai \\
\hline 1 & $\mathrm{X}_{1}-\mathrm{Y}_{1}$ & 0.298 \\
2 & $\mathrm{X}_{2}-\mathrm{Y}_{1}$ & -0.001 \\
3 & $\mathrm{X}_{3}-\mathrm{Y}_{1}$ & 0.714 \\
4 & $\mathrm{X}_{1}-\mathrm{Y}_{2}$ & 1.442 \\
5 & $\mathrm{X}_{2}-\mathrm{Y}_{2}$ & 0.027 \\
6 & $\mathrm{X}_{3}-\mathrm{Y}_{2}$ & -0.355 \\
7 & $\mathrm{Y}_{1}-\mathrm{Y}_{2}$ & -0.198 \\
\hline
\end{tabular}

Sumber: Data diolah

\section{SIMPULAN}

Berdasarkan hasil analisis dan pembahasan maka dapat disimpulkan sebagai berikut:

1. Tenaga kerja subsektor kehutanan berpengaruh positif dan signifikan terhadap pertumbuhan sektor kehutanan Kabupaten Berau.

2. Investasi pemerintah berpengaruh negatif dan tidak signifikan vterhadap pertumbuhan sektor kehutanan Kabupaten Berau.

3. Luas hutan produksi berpengaruh positif dan signifikan terhadap pertumbuhan sektor kehutanan Kabupaten Berau.

4. Tenaga kerja subsektor kehutanan berpengaruh positif dan signifikan terhadap kesempatan kerja Kabupaten Berau.

5. Investasi pemerintah berpengaruh positif dan tidak signifikan terhadap kesempatan kerja Kabupaten Berau.

6. Luas hutan produksi berpengaruh negatif dan tidak signifikan terhadap kesempatan kerja Kabupaten Berau.

7. Pertumbuhan sektor kehutanan berpengaruh negatif dan tidak signifikan terhadap kesempatan kerja Kabupaten Berau.

\section{DAFTAR PUSTAKA}

Affandi, Pratana. 2002. Menyejahterarakan Masyarakat di sekitar Hutan dengan Hutan Kemasyarakatan. Majalah Kehutanan Indonesia. Jakarta

Akdon. 2008. Aplikasi Statistika dan Metode Penelitian untuk Administrasi \& Manajemen. Bandung: Dewa Ruchi.

Anonim. 2014. Kabupaten Berau Dalam Angka 2014. Jakarta: Badan Pusat Statistik.

Anonim. 2014. Produk Domestik Regional Bruto Kabupaten Berau 2014. akarta: Badan Pusat Statistik

Anonim. 2014. Keadaan Angkatan Kerja Di Provinsi Kabupaten Berau. Edisi Agustus 2014. Jakarta: Badan Pusat Statistik Astuti, Setyaningrum dan Handoko. 2007. Ekonomi Pembangunan, Teori, Masalah dan Kebijakan. Cetakan Pertama. Unit penerbitan dan Percetakan Akademi Manajemen Perusahaan YKPN, Yogyakarta. Arief, A. 2001. Hutan dan Kehutanan. Kanisius. Yogyakarta.

Arsyad. Lincoln. 2007. Ekonomi Pembangunan Edisi Ketiga. Yogyakarta: Penerbit BP STIE YKPN.

Boediono. 2009. Teori Pertumbuhan Ekonomi. Yogyakarta: Penerbit BPFE. Davis, Johnson, 2007, Permintaan dan Nilai Manfaat Ekonomi, Penerjemah Herman Wibowo, Erlangga, Jakarta.

Irawan dan Suparmoko. 2007. Ekonomika Pembangunan Edisi Kelima. Yogyakarta: Penerbit BPFE.

Kadarusman, Y.B, dkk. 2004. Makro Ekonomi Indonesia. Jakarta. PT Gramedia Pustaka Indonesia. 
Kuncoro, Mudrajad. 2007. Ekonomi Pembangunan, Teori, Masalah dan Kebijakan Edisi Ketiga. Yogyakarta: Penerbit UPP AMP YKPN.

Makmun, Yasin dan Akhmad. 2003. Pengaruh Investasi dan Tenaga Kerja terhadap PDB Sektor Pertanian. Kajian Ekonomi dan Keuangan, Vol. 7, No. 3 Sept. 2003.

Mankiw, N. Greorgy. 2000. Teori Makor Ekonomi. Edisi Keempat. Alih Bahasa: Imam Nurmawam. Jakarta: Erlangga

Nafarin, 2000. Penganggaran Perusahaan. Penerbit: Salemba Empat. Jakarta.

Pamulardi, B. 1999. Hukum Kehutanan dan Pembangunan Bidang Kehutanan. PT RajaGrafindo Persada. Jakarta.

Prayitno, Hadi. 2009. Pengantar Ekonomika Pembangunan. Yogyakarta: BPFE. Program Magister Ilmu Ekonomi. 2014. Buku Pedoman Penulisan Usulan Penelitian dan Tesis. Universitas Mulawarman Samarinda.

Purwanti, Putu Ayu. 2009. Analisis Kesempatan Kerja Sektoral di Kabupaten Bangli dengan Pendekatan Pertumbuhan Berbasis Ekspor. Fakultas Ekonomi Universitas Udayana. Jurnal Ekonomi Pembangunan.Vol. 5, No. 1, 2009, ISSN 1907-3275.

Rasidin S, Bonar S. 2009. Dampak Investasi Sumber Daya Manusia Terhadap Pertumbuhan Ekonomi dan Kemiskinan di Indonesia. Prisma, Hal. 17- 31. No. 1.

Siahaan, Harlem. 2005. Kemiskinan Dan Pertumbuhan Ekonomi. Prisma. Hal. 17- 31. No. 1.

Simanjuntak, Payaman. 2005. Pengantar Ekonomi Sumber Daya Manusia. Jakarta. UI Press.

Situmorang, Erlina. 2007. Analisa Kebijakan Investasi dan Ketenagakerjaan di Provinsi Papua Barat. Papua Barat.

Sobita, Auparta. 2014. Pertumbuhan Ekonomi dan Penyerapan Tenaga Kerja di Provinsi Lampung. Tesis. Lampung.

Sodik (2007, 27-36), Pengeluaran Pemerintah dan Pertumbuhan Ekonomi Regional: Studi kasus data panel di Indonesia. Jurnal Ekonomi Pembangunan. Vol. 12. No 1, April 2007. Hal 27-36.

Suparmoko, M. 2000. Keuangan Negara Dalam Teori dan Praktek. BPFE Yogyakarta. Yogyakarta.

Sukirno, Sadono. 2003. Ekonomi Pembangunan. Jakarta: LP Universitas Indonesia.

Sukirno, Sadono. 2010. Makro Ekonomi Modern. Jakarta: Penerbit PT Raja Grafindo Persada.

Sugiyono. 2008. Statistik Untuk Penelitian. Bandung: CV. Alfabeta.

Sunyoto, Danang. 2010. Uji Khi Kuadrat \& Regresi untuk Penelitian. Yogyakarta. Graha Ilmu.

Sumaryono dan Redhahari, 2002. Pengaturan Hasil Hutan Produksi pada Era Desentralisasi. Lokakarya Pengelolaan Hutan Produksi di Kalimantan Timur.

Tambunan, Tulus H. 2010. Perekonomian Indonesia. Jakarta: Penerbit Ghalia Indonesia.

Tandiawan, Naukoko dan Wauran. 2013. Pengaruh Investasi Swasta dan Belanja Pemerintah terhadap Pertumbuhan Ekonomi dan Dampaknya terhadap Kesempatan Kerja di Kota Manado tahun 2001 2012. Tesis.

Tarigan, Robinson. 2005. Perencanaan Pembangunan Wilayah. Jakarta: Bumi Aksara.

Wardana, Budhi, Yasa. 2012. Faktor-Faktor yang Mempengaruhi Pertumbuhan Ekonomi dan Dampaknya terhadap Kesempatan Kerja di Provinsi Bali. Tesis. Universitas Udayana Denpasar. Bali.

Widodo, Joko. 2009. Analisis Kebijakan Publik. Malang: Bayumedia Publishing. 